\title{
Models of financial provision of the university transformation into regional center of innovations
}

\author{
Alla E. Kalinina \\ Volgograd State University, \\ Volgograd, Russia \\ allakalinina@volsu.ru
}

\author{
Aleksander G. Losev \\ Volgograd State University, \\ Institute of Mathematics and Information Technologies \\ Volgograd, Russia \\ alexander.losev@volsu.ru
}

\author{
Vasiliy V. Tarakanov \\ Volgograd State University, \\ Volgograd, Russia \\ rector@volsu.ru
}

\begin{abstract}
The article is devoted to the discussion of some models of financial, personnel and organizational provision of the university transformation into the center of innovation, technological and social development of the region. The forming of innovation and entrepreneurial university with academic nucleus and interdisciplinary project focused infrastructure which will provide personnel and intellectual assistance to the development of technology intensive industries and of social security in the region on the basis of the integration of science, education, production, institutes for development and socially focused non profit organizations requires new approaches to the problems of resource provision of corresponding programs. The suggested methodology is a natural sequel of ideas suggested in recent papers of the authors which have already had practical implementation in the Volgograd State University. Meanwhile the suggested methodology takes into account the requirements of the priority project "Higher educational institutions as innovation areas".
\end{abstract}

Keywords: financial management, resource provision, innovation center, mathematical model

\section{INTRODUCTION}

Over recent years more and more scientists start paying attention to the problems of university influence on regional development. As it was mentioned «besides traditional and research functions the university is involved into economic, social and cultural life of a region. In a broad sense the university is a leader and a driver of large scale activity which is needed for regional development» [1]. The priority project of the creation of university centers for innovation, technological and social development of a region adjusts the pace of reforms in Russia in the higher education for the solution of the tasks of regional development. This aspect is expected to be taken into account at the evaluation of the efficiency of work of separate universities and of the Russian education system in the whole. This project was approved October, 252016 by the Presidium of the Council at the President of the Russian Federation; it is part of a priority direction of the Russian development and is planned for year 2025. Upon the results of the competition the Volgograd State University (VolSU) received the title: center of technological, innovation and social development of the region.

The strategic goal of the transformation of the Volgograd State University into the University center for innovation, technological and social development of the region is the creation of innovation and entrepreneurship focused university with academic nucleus and interdisciplinary project oriented infrastructure which will provide personnel and intellectual assistance for the development of technology intensive industries of the economic and social sphere of the Volgograd region on the basis of the integration of science, education, production, institutes of development and socially oriented non profit organizations.

The program of the transformation of the Volgograd State University into the university center for innovation, technological and social development of the region mentions that the achievement of the strategic goal will be implemented by means of solving the following tasks:

- involvement of key stakeholders into the process of the development and implementation of principal and supplementary educational programs and the specification of the areas of applied scientific research. This will allow providing the capitalization of educational, scientific and technological results in the industries of the region;

- increase of international competitiveness of the Volgograd State University as a factor of human capital development and improvement of investment attractiveness of the Volgograd region;

- implementation of educational Bachelor, Master and Specialist programs oriented on project and implying the carrying out in team of the projects of a complete life cycle included into the enlarged groups of educational programs. 
They are «Computer and Information Sciences», «Earth Sciences», «Biology», «Informatics and Computation», «Information Security», «Electronics, radio technology and communication systems», «Photonics, tool making, optical and biotechnical systems and technologies», «Management in Technical Systems», «Nanotechnologies and Nanomaterials», «Economics and Management», «Political Sciences and Regional Studies», «Mass Media and Library Science», «Service and Tourism», «Pedagogical Education»;

- development and implementation of Master programs in technological entrepreneurship and management of technological projects with the involvement of enterprises of real sector of economy into the educational programs «Innovatics», «Science technologies and Innovation Economics», «Nanoengineering», «Economics», «Management», «Finance and Credit»;

- implementation of Master programs in social entrepreneurship and in project management with the involvement of real sector of economy including socially oriented non profit organizations of real sector of economy in the educational programs «Economics», «Management», «Finance and Credit», «Social work», «Jurisprudence», «Pedagogical education»;

- intensification of the system interaction with Federal Scientific Center of agricultural ecology of the Russian Academy of Sciences, Institute of Management Problems of the Russian Academy of Sciences, Center of crystallography and photonics of the Russian Academy of Sciences and other organizations by means of the creation of basic chairs, realization of joint educational programs including the net form, scientific research and technological developments;

- creation of the industrial engineering center in the realization of the projects in priority groups of technologies "Artificial Intelligence", "Big Data" from the National technological initiative, centers of the certification of supplementary professional qualifications in the block chains and informational security;

- development of organizational, consulting and financial infrastructure of the support of student technological and social entrepreneurship, creation and functioning of start up accelerators and programs of the assistance to student entrepreneurship with the help of development institutes;

- development of new programs and implementation of the existing educational programs in the growth of informational, financial and legal literacy of citizens, development of professional competence of instructors, education of the regional inhabitants, development of voluntarism.

Even a superficial analysis of the transformation program and of the road map of the enterprises shows that the university faces serious problems in the provision of this project with financial, material, technical and human resources. This article is devoted to financial and mathematical challenges of the solution of this problem.

\section{MATERIALS AND METHODS}

It is worth mentioning that the program of transformation includes a number of the projects which are referred to educational, scientific and research and other spheres of university activity. Let us classify them from the point of view of their provision with financial, human, material and technical resources. Herewith we will divide the human resources into two parts: research, pedagogical staff, management, materials, technical buildings, lecture rooms on the one hand and equipment and laboratory base on the other hand.

The first pool of the projects should be classified as educational activity of university. Into this group the following measures should be included: development on project oriented educational programs implying the team work of projects of full life cycle; programs of the technological entrepreneurship and management of technological projects; programs in social entrepreneurship and project management, creation of basic scientific chairs, organization of joint programs in the net form and others.

It can be said that in the organizational sense the Volgograd State University is prepared most for the realization of the programs from this pool. In the University the financial and mathematical model of the formation of salary fund of structural divisions within which the financing is made proportionally to the share of every chair in the educational process within every specific educational program. Such a description of the given model and the results of the introduction can be found in the sources [2],[3],[4]. In particular in the source [4] it is noted that the application of this methodology has lead to the fact that the largest part of the university chairs «accumulated financial reserves which allowed to transfer to the system of efficient contracts with professor, pedagogical staff and scientific workers within the available hierarchical system of the goals of scientific and educational activity». It is also mentioned in these sources that the given model contributes to the growth of independence (first of all financial one) of chairs and structural divisions and allows keeping the chairs as institutes only just changing their functions at the transfer to a popular today model of the management of educational programs.

The second pool of projects is connected with the programs of the strategic initiative «University as an integrating unit of the formation of technological and entrepreneurial infrastructure of the Volgograd region and the implementation in the region of the projects launched by National technological initiative». Within this pool of projects the creation of a number of engineering centers, centers of collective use and centers for expert consulting connected with the existing in the university excellence centers and scientific laboratories is planned.

In the organizational sense the implementation of the largest part of programs from this pool of projects in the existing excellence centers and scientific and research institutes and laboratories is expected [5]. However for the efficient work of similar division the corresponding financial provision is needed. In this case the following approach is suggested. The estimate of costs in practically all scientific 
grants and other scientific and research projects includes the stipulation in the contract which implies the reimbursement of expenses of the organization providing premises for the project implementation. In many cases it makes up from 10 to $20 \%$ of the total financing. Herewith in most cases the expenses of the organization for the implementation of a project are easily calculated and do not make up the largest part of the project. The remaining funds in many cases the university spends on various projects, for instance on bonus payment for the staff for publications indexed in international databases. It seems reasonable enough to spend the largest part of this type of finance on the provision of programs in which the corresponding grants are included.

The possible co financing of the programs from budgetary and non budgetary funds of the university can be implemented within the approach suggested in the article [6]. For the calculation of the salary fund of the employees involved into the organizational and the project support of a corresponding program the following algorithm is suggested. Let us mark $\boldsymbol{F}_{\boldsymbol{I}}$ the salary fund of the employees involved into the implementation of this program in the given year, $\boldsymbol{S}_{\boldsymbol{I}}$ is the volume of financing of the scientific component of this program in the current year, $\boldsymbol{S}_{2}$ is the value forecasted for the next year. Thus the salary fund of the employees for the next year will be calculated using the following equation: $F_{2}=F_{1} f\left(\frac{S_{2}}{S_{1}}\right)$, $F_{2}=$ where $f(x)$ is an increasing function. The mentioned approach provides a stable and continuous implementation of the program.

The third pool of the projects is connected with the programs of the strategic initiative «Development of the innovation ecosystem of the university, involvement of students, post graduate students and lecturers into the entrepreneurial activity».

The largest part of the programs of this pool of projects is closely connected with moral building and educational projects. In this case it is looks quite reasonable to use personnel, scientific, methodical, organizational, managerial and informational resources for the moral building work in the university. However as in the previous pool of projects it is worth providing the continuous financing of the planned programs. Taking into consideration the fact that almost all the programs of this pool are closely related with the plans of the works of real institutes of the university it looks reasonable enough to attract non budgetary funds of the corresponding institutes. At the calculation of the salary fund of the employees involved into the organizational and the project support from this pool it is suggested to use the methodology mentioned above for the implementation of the programs of the second pool.

\section{RESULTS AND DISCUSSION}

The possibility and the necessity of the transformation of the Volgograd State University, on the basis of which the implementation of the suggested approach will be carried out, into the university center of innovation, technological and social development of the region, is quite obvious and founded. On the one hand the Volgograd region has considerable industrial, scientific, technological and investment potentials. On the other hand during recent years the negative tendencies of the reduction of the gross regional product, of the migration outflow of the population and the reduction of the number of economic actors are observed. The creation of the center of this kind will help overcome the negative trend of migration outflow; it will help encourage innovative development of the regional economy.

The achievement of a high level of the involvement of the university into the solution of the tasks of innovative, technological, social and economic development of the region will allow solving a number of serious problems. The mentioned project is implemented on the basis of the signed agreements and contracts and other normative and legal documents approved by the President of the Russian Federation, Governor of the Volgograd region, regional and municipal authorities. Herewith the implementation of this project from the part of the Volgograd State University is provided by considerable personnel, financial and organizational resources. As it is mentioned in the program of the transformation of the Volgograd State University into the university center of the innovation, technological and social development of the region, the volume of proper funds in the financial provision of the program in 2018 makes up $67 \%$, in 2019 it will amount to $71 \%$. The total budget of the program for three years makes up more than 100 billion rubles. Under such conditions by no means unimportant or even decisive role in the successful implementation of the mentioned program has a rational or optimal use of available resources.

It is quite possible that in the process of the realization the suggested model of the use of resources will be subject to a certain correction however the existing experience allows considering its main provisions as quite justified.

\section{CONCLUSION}

During recent years the research devoted to the strategic financial management of higher educational institutions including the development of methods and algorithms of analysis, planning and management of educational process and also of financial and economic activity are published more and more often [2]-[8]. At the same time under the conditions of continuous changes of the educational program list, of the uncertainly in the financial provision of scientific and research projects, growth of the role of the regional aspect in the assessment of the efficiency of higher education, the complexity of the decision making grows several fold. The necessity of the development of a formalized mathematical description of the processes at the first stage of the creation of the optimization models including the multi criteria model of the decision taking under the condition of uncertainty has become urgent. The latter will provide the development and the introduction into the strategic financial management of higher educational institutions of modern informational systems as a tool of an optimal decision making. 


\section{Acknowledgment}

This research was financially supported by the Russian Fund for Fundamental Research and the Administration of the Volgograd region, project «Financial and mathematical models and algorithms of the budgeting of structural departments of educational organizations» №17-12-34015.

\section{References}

[1] Kranzeeva E.A. "New Models of Universities: Contribution to Regional Development" [Novie Modeli Universitetov: Vklad v Regional'noe Razvitie], University Management: Practice and Analysis [Universitetskoe upravlenie: praktika i analiz], 2016, no. 5 (21), pp. 64 - 73.

[2] Korolkov S.A., Losev A.G., Reshetnikova I.M., Tarakanov V.V. "Budgeting model of structural units based on normative per capita funding", European researcher, Series A, 2014, Vol. 70, no. 3-1, pp. 498-508.

[3] Korolkov S.A., Losev A.G., Tarakanov V.V., "Education Programs Management by Education and Finance Plans Implementation" [Upravlenie obrazovatel'nymi programmami cherez vnedrenie uchebno-finansovykh planov], University Management: Practice and Analysis [Universitetskoe upravlenie: praktika i analiz], 2016, no. 4 (104), pp. 50 - 56.

[4] Korolkov S.A., Losev A.G., Tarakanov V.V. "Model of Financial Support for the Implementation of Target Indicators of Efficiency of the University" [Model' finansovogo obespecheniya vypolneniya tselevykh pokazatelei effektivnosti raboty vuza], University Management: Practice and Analysis [Universitetskoe upravlenie: praktika i analiz], 2017, Vol. 21. № 6, pp. 49 57.
[5] Kalinina A.A., Tarakanov V.V. Organizatsionno-finansovoe obespechenie razvitiya nauchno-innovatsionnoi infrastruktury universiteta. - Intellektual'nyi vklad v tekhnologiyu uspekha regiona: katalog ob'ektov intellektual'noi sobstvennosti uchenykh Volgogr.gos.un-ta. Pod obshch. redaktsiei A.E. Kalininoi [Organizational and financial support of the development of scientific and innovation infrastructure of the university. - Intellectual contribution to the technology of success of the region: catalogue of the objects of the intellectual property of the scientists of the Volgograd university. Edited by A.E. Kalinina]. Volgograd: Izd-vo VolGU Publ., 2016, pp. 7 - 15

[6] Losev A.G., Loseva N.V., Tarakanov V.V. "The Mathematical Model for Budgeting of Structural Subdivisions of Higher Educational Institutions" [Matematicheskaya model' obespecheniya budgetov strukturnih podrazdeleniy vuzov], Regional Economy. South of Russia [Regional'naya ekonomika. Yug Rossii], 2017, № 4(18), pp. 160 - 168.

[7] Filipenko N.V., Poluboyarov V.V. "Implementation of the Financial Planning System Using the Intra-University Information Support System of the Financial Planning Process" [Vnedrenie sistemi finansovogo planirovaniya $\mathrm{s}$ ispol'zovaniem vnutrivuzovskoy informacionnoy sistemi], University Management: Practice and Analysis [Universitetskoe upravlenie: praktika i analiz], 2017, Vol. 21. № 6, pp. 58 - 67.

[8] Alashkevich M.Y., Zarubin A.V., Merkulov M.V., Grishkin V.V., "Developing Instruments for Quality Improvement of University Financial Management in the Context of Budget reform" [Razvitie instrumentov povisheniya kachestva finansovogo menedgmenta obrazovatel'nih uchrejdeniy $\mathrm{v}$ usloviyah budgetnoy reformi], University Management: Practice and Analysis [Universitetskoe upravlenie: praktika i analiz], 2016, Vol. 104. № 4, pp. 9 - 14. 